\title{
State Succession and International Watercourses: the role that the 1978 Vienna Convention and the Case of Gabćíkovo- Nagymaros Project could play
}

\author{
Adela M. AURA Y LARIOS DE MEDRANO*
}

\begin{abstract}
The existence of international watercourses in the territory where a secession phenomenon occurs brings with it important and specific legal problems related to the succession of States, which this paper deals with: in relation to the membership of international organizations; with respect to the succession of States in respect of State property; and, last but not least, with reference to the succession of States in respect of treaties, particularly in respect of international agreements on international watercourses. With regard to the latter, this paper analyses the argument given by the International Court of Justice in the Case of Gabćíkovo-Nagymaros Project, and reviews the work of the International Law Commission for the purpose of the progressive development of International Law and its codification on the topic of the succession of States; in the hopes that by searching for rules and general principles, solutions could be found for other cases.
\end{abstract}

Keywords: State Secession - State Succession - International Watercourses.

\section{(A) INTRODUCTION}

The creation of South Sudan, as a result of the choice of the people of southern Sudan for secession during the January $201 \mathrm{I}$ referendum, ${ }^{\mathrm{I}}$ has modified the riparian States in the Nile Basin and has brought about certain questions about the situation of the new State in this respect.

The topic of the succession of States in the case of the secession is, without doubt, an issue of special relevance and one which has once again become pertinent in International Law. The said relevance and complexity increase when international watercourses exist in the territory

Associate Professor of Public International Law, CEU Cardenal Herrera University. E-mail: aura.el@uchceu.es. This paper has been prepared in relation to the activities of the Research Project "La Unión Europea ante los Estados fracasados de su vecindario: retos y respuestas desde el Derecho internacional (II)" DER2015-63498-C2-2-P.

I South Sudan gained independence from Sudan on 9 July 20II, after a referendum. On I4 July 20II, the General Assembly decided to admit the Republic of South Sudan to membership of the United Nations (GA Res. 65/308, I4 July 2011).

It is important to note that the representative of South Africa, sponsor of a draft resolution, said "African heads of State and Government acknowledge that the Sudan represents an exceptional case that does not negate the sacrosanct principle of respect for colonial borders. I stand here before the General Assembly with the distinct honour to introduce, on behalf of the Group of African States, the draft resolution on the admission of the Republic of South Sudan to membership in the United Nations, comfortable in the knowledge that this act in no way creates a precedent for secessionist tendencies" (A/65/PV.Io8, at 2). 
in which secession occurs. In summary: What rights and duties does a new State retain with respect to legal obligations undertaken by its predecessor State?

In an attempt to shed light on this topic, the paper first begins with secession and succession; later, it covers the relationship with international watercourses, and highlights the different areas in which problems arise. Subsequently, the problem of the succession of States in respect of international water treaties will be analysed.

As far as the way in which one proceeds, the methodology is twofold: firstly, this paper analyses the argument given by the International Court of Justice (ICJ) in the Case of Gabćíkovo-Nagymaros Project; ${ }^{2}$ therefore, the main object of this part of the research is the study of the succession of Slovakia in the 1977 Treaty; 3 secondly, this paper reviews the work of the International Law Commission (ILC) for the purpose of the progressive development of International Law and its codification on the topic of the succession of States in respect of treaties.

The work concludes by answering the question in the title about the role of the 1978 Vienna Convention ${ }^{4}$ and the Case of the Gabčíkovo-Nagymaros Project.

\section{(B) STATE SECESSION AND STATE SUCCESSION}

The State secession phenomenon - when part or parts of State territory withdraw from a State with the will to create a new State or states - always entails territorial modifications. The succession of States rules can be applied, sometimes, to these territorial modifications. Thus, succession of States is a very relevant topic in International Law nowadays.

As a general statement, the problem of the succession of States arises in relation to territorial transformations. This is true, no matter what the origins of the said modifications: in the sixties, these and the new States were the results of the decolonization process; ${ }^{6}$ currently, they are the product of the disintegration of States and of cases of secession.7

Notwithstanding the above, the origin of the territorial modification will definitely influence the solution to the problem of succession. In effect, when it talks of the succession of States in International Law, it usually refers as much to the process of creation and disappearance of

\footnotetext{
2 Case concerning the Gabčḱkovo-Nagymaros Project (Hungary/Slovakia), Judgment of 25 September 1997, ICJ Reports (1997) 7-84. Hereinafter Gabč́́kovo Case.

3 See note $2 \mathrm{I}$.

4 Vienna Convention on Succession of States in respect of Treaties (done at Vienna on 23 August 1978, entered into force on 6 November 1996) 1946 UNTS 3. Hereinafter 1978 Vienna Convention.

5 J.D. González Campos, 'Algunas consideraciones sobre los problemas de la sucesión de Estados', XVI Revista Española de Derecho Internacional (1963) 55I-578, at 567.

6 The GA Res. I5I4 (XV), I4 December 1960 was a milestone.

7 They gave rise to the emergence of many new European States in the last few decades.
} 
States as to the legal consequences of these transformations. ${ }^{8}$ Therefore, it is affirmed that the cause of State succession is always a territorial modification occurring in conformity with International Law. Thus, both the 1978 Vienna Convention and the 1983 Vienna Convention 9 apply only to the effects of a succession of States occurring in conformity with International Law and, in particular, with the principles of International Law embodied in the Charter of the United Nations. Precisely for this reason, the succession of States rules can only be applied at times to the State secession phenomena. Thus, it is affirmed that an illegal territorial modification, such as one brought about by the unlawful use of force, ${ }^{\text {,o }}$ would not be recognized nor ruled by International Law.

\section{(C) SECESSION, STATE SUCCESSION AND INTERNATIONAL WATERCOURSES}

Where there are watercourses in the territory that produces the secession, the political composition of the international basins usually changes. It is possible for watercourse States ${ }^{\text {II }}$ to change or for the number of riparian States to increase. This is not hypothetical as it has happened at the Danube and the Nile.

After the dismemberment of the USSR, Yugoslavia and Czechoslovakia (this is the case that interests us most) changes were produced in the States of the Danube River Basin; in addition, their number increased. In the case of the River Nile, its flow extended over the territory of ten States and, after the creation of South Sudan, to eleven States.

We have already said that the main object of the research is the study of the 1977 Treaty between Hungary and Czechoslovakia (which resulted in the Gabčíkovo Case) with the hope that by searching for rules and general principles, solutions could be found for other cases, as the Nile. There are a lot of unsolved problems related to the situation that secession and the birth of South Sudan brought about in the Nile. Among these, the most urgent is to know the situation of this new State in the basin, particularly its legal position in relation to the 1959 Agreement signed by Egypt and Sudan.

The following sections will refer to the succession of States in respect of international watercourses treaties. First, it should be noted that the existence of international watercourses in territory where a secession phenomenon occurs brings with it other legal problems, both in

8 C. Jiménez Piernas, Introducción al Derecho Internacional Público. Práctica de España y de la Unión Europea (Tecnos, Madrid, 20II), at I8I.

9 Art. 6 of the 1978 Vienna Convention and art. 3 of the Vienna Convention on Succession of States in respect of State Property, Archives and Debts (done at Vienna on 8 April 1983, not yet in force).

Io Accordance with International Law of the Unilateral Declaration of Independence in respect of Kosovo, Advisory Opinion of 22 July 2010, ICJ Reports (2010), at paragraphs 8I, 84 and 122.

II State in whose territory part of an international watercourse is situated. 
relation to the membership of international organizations and with respect to the succession of States in respect of State property.

In relation to the membership of international organizations various questions arise. On the one hand, specific problems emerge when succession affects States that form part of international basins, which is the theme of the succession in the Commission of International Rivers. Therefore, for example, Slovakia replaced Czechoslovakia in the Danube Commission, ${ }^{12}$ simply by sending a letter dated the I2 December 1992, written by the Minister of Foreign Affairs of the Slovak Republic to the Director General of the Danube Commission, ${ }^{13}$ based on the Tripartite Agreement on Membership in International Organizations. ${ }^{14}$

On the other hand, general problems must also be considered, especially owing to their consequences, when the international basin is linked to an International Organization sui generis for regional integration. When it is linked with a special subsystem of International Law such as European Union Law to which, prima facie, only members of the European Union are bound.

In the event of secession of territories in a member State of the European Union, only the said State will retain its membership to the organization, and the new State will form a third State outside the European Union. ${ }^{16}$ Consequently, it will no longer be bound by the environmental policy of the European Union. This would be a serious problem for the rest of the member States, because the European Union has some of the world's highest environmental standards. ${ }^{17}$

Secondly, specific problems of succession of States could arise in the case of real property situated outside the territory of the pre-existing State; these problems should be solved by the principle of equity, not by the principle of territory. ${ }^{18}$ In addition, more problems arise with

I2 The Commission set up by the Convention regarding the Regime of Navigation on the Danube (adopted I8 August 1948 in Belgrade, entered into force on II May 1949). A non-official version in English: Danube Commission Web.

I3 J. Klabbers, M. Koskenniemi, O. Ribbelink, A. Zimmermann (editors), State Practice Regarding State Succession and Issues of Recognition (Brill Nijholl, Leiden, 1999), at 494.

${ }^{14}$ K.G. Bühler, State Succession and Membership in International Organizations (Kluwer Law International, The Hague, 200I), at 275.

is A. Mangas Martín, 'European Union Law: a Special Subsystem of International Law', in Liber Amicorum of Judge José María Ruda (Kluwer Law international, La Haya, 2000), 585-593, passim.

${ }_{16}$ A. Mangas Martín, 'La secesión de territorios en un Estado miembro: efectos en el Derecho de la Unión Europea', 25 Revista de Derecho de la Unión Europea (julio-diciembre 2013) 47-68, at 58-60.

${ }_{17}$ The EP and Council Directive 2000/60/EC of 23 October 2000, establishing a framework for Community action in the field of water policy, OJ $2000 \mathrm{~L} 327 / \mathrm{I}$, considered this to be a problem and attempted to solve it with art. 3.5. However, while member States are obliged to apply the rules of the directive, the non-member States are not (C. Tirado Robles, La Política del Agua en el Marco Comunitario y su Integración en España (Thomson Aranzadi, Navarra, 2004), at 8I.

I8 T. Ushakova, La sucesión de Estados en materia de bienes, archivos y deudas: el caso de la URSS (Editorial 
the existence of real property of a third State (such as the public works concession contract for the construction, management, operation and maintenance of such property).

\section{(D) SUCCESSION OF STATES IN RESPECT OF TREATIES: INTERNATIONAL WATER TREATIES}

In relation to the succession of States in respect of agreements on international watercourses, there are relevant questions: What happens with multilateral treaties signed by the predecessor State? And what about bilateral treaties? Are these treaties no longer in force or are they still in force in the territory of the drainage basin despite any State secession? What will be the territorial scope of the treaties that remain in force? Would the territory which is subject to secession be included in this scope or would it be outside of it? What happens about the rights and duties of third States, especially with lower riparian States? In summary, what rights and duties does a new State retain with respect to legal obligations undertaken by its predecessor State?

As the following pages explain, it is not possible to give general answers to such questions; the answers will be different depending on the nature of each water treaty. In addition, the answers could vary within treaties of an analogous nature according to whichever agreement it relates to. This is because the geographic particularism of international watercourses has consequences for the law of international watercourses, which is infused by two opposing tensions: Particularism Vs Universalism and the Fragmentation of International Law Vs General Law.19

These tensions explain the existence of conventions which only regulate some of the uses of international watercourses, for example, only the demarcation of boundaries, navigational use or the production of hydroelectric energy and only in one river. More recent treaties carry a broader scope: to cover all uses of international water resources as well as management and environmental protection. ${ }^{20}$

To sum up, hundreds of treaties on international watercourses differ greatly and are very diverse in nature. This summary explains the main conclusion of this paper: the problem of the succession of States in respect of water treaties has to be considered case by case. The most pertinent consideration has to be the nature of the treaty in question (the number of parties,

\footnotetext{
Universitaria Ramón Areces-Universidad de Alcalá, Madrid, 2006), at 78-79.

I9 See 'La labor de la CDI: problemas, tensiones y opciones', in A. Aura y Larios de Medrano, La regulación internacional del agua dulce. Práctica española (Thomson-Aranzadi, Navarra, 2008), at 52-73.

${ }_{20}$ Such as art. 3 Convenio sobre cooperación para la protección y el aprovechamiento sostenible de las aguas de las cuencas hidrográfica hispanoportuguesas, hecho "ad referendum" en Albufeira el 30 de noviembre de 1998, at BOE 37, I2 de February 2000. A non-official version in English is available at A. Mendes, F. Octavio de Toledo (Coordinators), Luso-spanish treaties. A centennial bistory of cooperation (Instituto da Água-Dirección General del Agua, 2009), at 28-72. See A. Aura, op. cit., at 23I-233.
} 
whether the treaty is bilateral or multilateral, is less relevant).

(E) THE I978 VIENNA CONVENTION AND THE CASE OF GABČÍKOVO-NAGYMAROS PROJECT

\section{(I) Overview}

In the Gabč́kovo Case, the ICJ considered that the 1977 Treaty" "cannot be affected by a succession of States". The ICJ found that the 1977 Treaty, signed by Hungary and Czechoslovakia, was still in force, notwithstanding the dismemberment of Czechoslovakia. The Court therefore concluded that "the 1977 Treaty became binding upon Slovakia on I January 1993". ${ }^{22}$ Thus, the relationship between Hungary and Slovakia was governed by the 1977 Convention. That relationship was also determined by the rules of other relevant conventions to which the two States are party, by the rules of general International Law and, in this particular case, by the rules of State responsibility; "but it is governed, above all, by the applicable rules of the 1977 Treaty as a lex specialis".23

The ICJ argued its assertion in article I2 of the 1978 Vienna Convention, considering the nature and character of the 1977 Treaty. Hungary never signed or ratified the 1978 Vienna Convention. Thus, the ICJ discussed whether article I2 of the 1978 Convention reflects the state of customary International Law; and it found that article I2 does reflect a rule of customary International Law. Therefore, the ICJ did not find it necessary to analyse article 34 of the 1978 Vienna Convention, the law governing the "Succession of States in cases of separation of parts of a State" (that is, in the case of secession).

This section will refer to the articles 34 and 12 of the 1978 Vienna Convention, in relation to the Draft Articles adopted by the ILC, ${ }^{24}$ and to the documents of the UN Conference; ${ }^{25}$ also, it will refer to Gabčíkovo Case, with regard to these articles. Secondly, the role that both could

${ }_{21}$ The Treaty on the Construction and Operation of the Gabtikovo-Nagymaros Barrage System and related instruments (signed in Budapest by Czechoslovak Socialist Republic and Hungarian People's Republic, on 16 September 1977), 1724 UNTS I20.

${ }_{22}$ Gabčíkovo Case, par. 123. Note that on I9 January 1993 the General Assembly decided to admit the Czech Republic (GA Res. 47/22I, I9 January 1993) and the Slovak Republic (GA Res. 47/222, I9 January 1993) to membership of the United Nations. See A. Aura, op. cit., at I54-166.

23 Gabčíkovo Case, par. I32.

24 "Report of the ILC on the work of its twenty-sixth session, 6 May -26 July 1974, Official Records of the General Assembly, Twenty-ninth session" (A/96Io/Rev.I).

${ }_{25}$ The Official Records of the United Nations Conference on Succession of States in Respect of Treaties consist of three volumes: A/CONF.80/16, A/CONF.80/16/Add.I, A/CONF.80/16/Add.2. 
play in other cases will be studied.

\section{(2)1978 Vienna Convention and the Gabčíkovo Case}

Considering that the situations in which new States are created vary enormously, ${ }^{26}$ the 1978 Vienna Convention basically foresees two different scenarios for State succession in respect of treaties: the "clean slate" principle or tabula rasa applies for newly independent States; ${ }^{27}$ and "universal continuity" applies for most other cases of the emergence of new States, including those in which one State separates from another State, regulated only by article $34 .{ }^{28}$ Therefore, all situations are divided into two groups completely differentiated by the 1978 Vienna Convention, according to the colonial past of the new State. Nonetheless, the situation was very different in the ILC Draft Articles, because the project of article 34 also provided, for certain situations, the tabula rasa rule for new States without colonial heritage. ${ }^{29}$

Slovakia argued that the 1977 Treaty remained in force between itself, as successor State, and Hungary, with support from the general rule of automatic succession imposed by article 34, in the Gabčíkovo Case, as first argument. But the ICJ did not find it necessary to enter into a discussion about whether or not article 34 reflected a customary rule, and focussed on analysing article 12 of 1978 Vienna Convention,,$^{30}$ because Slovakia's second argument rested on "the principle of ipso jure continuity of treaties of a territorial or localized character", the rule that Slovakia said is embodied in this article.

Article I2, under the title of "Other Territorial Regimes", provides that rights and obligations of a territorial character established by a treaty are unaffected by a succession of

26 See section $B$.

${ }_{27}$ Art. 2, Use of terms, states that "I.For the purposes of the present Convention: (f) 'newly independent State' means a successor State the territory of which immediately before the date of the succession of States was a dependent territory for the international relations of which the predecessor State was responsible". A detailed regulation of this scenario is given at arts. 16-30, in the Part III "Newly independent States".

28 In Part IV "Uniting and separation of States".

29 When the Commission was developing its draft articles, art. 33 (later changed to art. 34), the paragraph 3 stated: "Notwithstanding paragraph I, if a part of the territory of a State separates from it and becomes a State in circumstances which are essentially of the same character as those existing in the case of the formation of a newly independent State, the successor State shall be regarded for the purposes of the present articles in all respects as a newly independent State" (n. 24, at 260).

This paragraph was deleted at the UN Conference, at its 49th meeting: the Committee of the Whole voted by roll-call on the second part of the amendment submitted at the 1977 session by France and Switzerland (A/CONF.80/C.1/L4I/Rev.l) seeking to delete paragraph 3 of article 33. The amendment was adopted by 52 votes to 9, with 22 abstentions; It was adopted without discussion, as a consequential amendment to article 2.

30 Art. I2.2: "A succession of States does not as such affect: (a) obligations relating to the use of any territory, or to restrictions upon its use, established by a treaty for the benefit of a group of States or of all States and considered as attaching to that territory; (b) rights established by a treaty for the benefit of a group of States or of all States and relating to the use of any territory, or to restriction". 
States. This article together article $\mathrm{II}^{3 \mathrm{I}}$ should be understood as a limit or exception to the tabula rasa principle (which was the rule not only for cases of newly independent States but also for cases that may be assimilated to them at ILC Draft Articles), as explained the ILC.32 In other words, the ILC believed that for the principle of the absence of any general obligation upon the successor State to consider itself bound by treaties concluded by its predecessor to be acceptable, it was essential that certain types of treaties should be regarded as having binding force on the successor State, as treaties relating to boundary regimes and other forms of territorial regimes. The reports of Special Rapporteurs and oral and written comments of Governments ${ }^{33}$ have made it clear that articles II and 12 reflect customary international law; nevertheless, neither the precedents nor the opinions of writers give clear guidance as to the criteria for determining when article $\mathrm{I} 2$ operates. 34 The UN Conference adopted articles II and I2 (only amended by the addition of the third paragraph).35

The ICJ confirmed that article I2 reflects a rule of customary international law in the Gabčíkovo Case; and it notes that neither of the Parties disputed this. But Hungary denied that the 1977 Treaty was a "localized" treaty within the meaning of article 12 of the 1978 Convention because Hungary considered that the 1977 Treaty was simply a joint investment. Nonetheless, the Court found that the content of the 1977 Treaty ${ }^{36}$ indicates that it must be regarded as establishing a territorial regime within the meaning of article 12 of the 1978 Vienna Convention: It created rights and obligations "attached to" the parts of the Danube to which

3I That stipulates that State succession does not affect boundaries established by a treaty or rights and obligations established by a treaty that relate to a boundary regime

32 The ILC was of the opinion that the main implication of the principle of self-determination in the law concerning succession in respect of treaties was precisely to confirm the traditional clean slate principle as the underlying norm for cases of newly independent States or for cases that may be assimilated to them (...) In addition, the clean slate principle does not, in any event, relieve a newly independent State of the obligation to respect a boundary settlement and certain other situations of a territorial character established by treaty (A/96ro/Rev.I at 169).

33 See "First report on succession of States in respect of treaties", by Sir Francis Vallat, Special Rapporteur (A/CN.4/278 and Add.I-6, at pars. 417-462).

34 "Some further precedents of one kind or another might be examined, but it is doubtful whether they would throw any clearer light on the difficult question of territorial treaties" (Ibid at 207).

See C. Leb, M. Tignino, 'State succession to water treaties: uncertain streams', in L. Boisson de Chazournes, C. Leb, M. Tignino (Eds.), International Law and freshwater. The multiple challenges (Edward Elgar, Cheltenham, 20I3), 42I-444, at 443. They suggest that "a general categorization of water treaties as territorial treaties and thus the application of the principle of automatic succession are inadequate".

${ }_{35} \mathrm{~A} / \mathrm{CONF} .80 / \mathrm{I} 6 /$ Add.2, at $153-155$ and 189 .

36 "An examination of this Treaty confirms that, aside from its undoubted nature as a joint investment, its major elements were the proposed construction and joint operation of a large, integrated and indivisible complex of structures and installations on specific parts of the respective territories of Hungary and Czechoslovakia along the Danube. The Treaty also established the navigational regime for an important sector of an international waterway, in particular the relocation of the main international shipping lane to the bypass canal. In so doing, it inescapably created a situation in which the interests of other users of the Danube were affected" (at par. I23). 
it relates; thus the Treaty itself cannot be affected by a succession of States.

In the Gabčíkovo Case the ICJ gave specific meaning to the vague concept of "territorial treaties"; so, the ICJ did in this Judgment what the ILC could not do in its commentaries, nor the UN Conference in its records. Nevertheless, the decision of the Court in the Gabćíkovo Case does not completely resolve the question of the scope of article 12, and leaves room for alternative interpretations. 37

(3) The role that the 1978 Vienna Convention and the Gabćíkovo Case could play This analysis of the Gabćíkovo Case, in relation to the 1978 Vienna Convention and the ILC Draft Articles, has been made by searching for rules and general principles to help clarify other cases, such as the unsolved problem of the legal position of South Sudan in the Nile Basin,,$^{8}$ particularly in relation to the 1959 Nile Waters Agreement, ${ }^{39}$ which focuses mainly in water allocation. $4^{40}$

The first thing to be pointed out is that the 1978 Vienna Convention per se is not applicable between the above-mentioned States. ${ }^{4 i}$ However, article 12 of the 1978 Convention can be applied, because the ICJ has affirmed it reflects a rule of customary International Law. So, the issue is to determine if the 1959 Agreement is a territorial treaty, or at least if it creates a

37 See Separate Opinion of Judge Bedjaoui, at pars. 20-26. He considers that the majority of the Court has not sufficiently clarified the question of the nature of the 1977 Treaty and of the applicable law. He said that the 1977 Treaty is a territorial treaty, is a treaty to which Slovakia validly succeeded, and is treaty which is still in force today; and he explains the reasons in which this assertions are based.

${ }_{38}$ As a former part of Sudan governed under that treaty, is the new State of South Sudan obligated to continue to abide by its terms?

In 2onI, South Sudan seceded from Sudan. Prior to secession, Sudan and Egypt had allocated water rights to the Nile according to the terms they negotiated under the 1959 Nile Waters Agreement. This agreement of 8 November 1959 is, in essence, a renegotiation of the agreement that Egypt signed with Great Britain on 7 May 1929. The agreement of 1959 benefits Sudan and Egypt enormously; in fact, it attributes almost $90 \%$ of the waters to them, because derivations of water upstream are forbidden without their consent, which prejudices upper river states (see art. 5.2 of the 1959 Agreement). For this reason, The Nile Basin Initiative (NBI), an intergovernmental partnership, was created in 1999 .

See Salman M.A. Salman, 'The new state of South Sudan and the hydro-politics of the Nile Basin', 36-2 Water International (March 201I) I54-I66, at I58-I59.

39 Agreement between the Republic of the Sudan and the United Arab Republic for the full utilization of the Nile waters (signed at Cairo, 8 November 1959, entered into force I2 December 1959) 453 UNTS 5I (available electronically at $\mathrm{FAO}$ web).

40 The agreement begins by fixing as the parties "established rights" the amounts of water actually being used by them as of de date of its conclusion (art. I), and it increases water allocations to both Egypt and Sudan (art. 2). The treaty authorizes the construction of some projects (art. 3) and it also established a Permanent Joint Technical Commission for cooperation between the States (art. 4)

${ }_{41}$ Egypt became a Party to the Convention, but Sudan only signed but never ratified it and South Sudan neither signed nor ratified it (Status of Treaties Deposited with the Secretary-General (UNTREATY, accessed 25 July 2018). 
territorial regime. So, the main question that arises is whether, or not, a territorial regime is created by water allocation provisions (in the same way that 1977 Treaty provisions $\mathrm{did}^{\mathrm{it}} \mathrm{t}^{2}$ ). As we have stated previously, the decision of the Court in the Gabčíkovo Case leaves room for diverse interpretations. ${ }^{43}$

\section{(F) CONCLUSIONS}

The geographic particularism of international watercourses has a consequence: agreements on international watercourses differ greatly and are very diverse in nature. Consequently, it is not possible to give general answers to the problem of the succession of States in respect of water treaties. The issue has to be considered case by case, and the most pertinent consideration has to be the nature of the treaty in question; the number of parties, whether the treaty is bilateral or multilateral, is less relevant.

In the Case of the Gabčíkovo-Nagymaros Project, the ICJ based its reasoning on article I2 of the 1978 Vienna Convention, considering the nature of the 1977 Convention (the particular provisions in this agreement). Therefore, the decision of the Court in the Gabćíkovo Case would play a limited role in attempting to resolve disputes between States at other cases.

42 See supra n. 36

43 Mohamed S. Helal, who used to work as Egyptian Diplomatic before being Assistant Professor of Law, considers that water allocation provisions created territorial rights that have survived South Sudan's secession from Sudan. So, "Sudan and South Sudan have to enter inter negotiations on the allocation of their common share of 18.5 bcm vis-à-vis Egypt, as established by the 1959 Nile Agreement". See M. S. Helal, 'Inheriting International Rivers: State Succession to Territorial Obligations, South Sudan, and the 1959 Nile Waters Agreement', 27 Emory International Law Review (2013) 907-985, at 979-980 and 983.

However, the author of this paper notes that the regime created by water allocation provisions at 1959 Agreement only for Parties, is very different from the navigational regime created by the 1977 Treaty, which recognized rights both for Parties and other users of the Danube River. 